\title{
U.S. Leadership and International Order: The Future of American Foreign Policy
}

\author{
Review Essay
}

\author{
John Kane \\ Department of Politics and Public Policy, \\ Centre for Governance and Public Policy, \\ Griffith University
}

Anne-Marie Slaughter, The Idea That is America: Keeping Faith with Our Values in a Dangerous World, New York: Basic Books, 2007, 254pp., hardcover US\$25.95.

G. John Ikenberry, Thomas J. Knock, Anne-Marie Slaughter and Tony Smith, The Crisis of American Foreign Policy: Wilsonianism in the Twenty-first Century, Princeton: Princeton University Press, 2009, 168pp., hardcover US\$24.95.

Robert Kagan, The Return of History and the End of Dreams, New York, A.A. Knopf, 2008, 116pp., hardcover US\$19.95.

Simon Bromley, American Power and the Prospects for International Order, Cambridge, Polity, 2008, 241pp., paperback £29.95.

The closing of a dismal chapter in American foreign policy has provoked a predictable flood of literature on what went wrong and why (and, less frequently, on what went right and how). The extensive post-mortem seems urgent, not merely for exposing the arrogance and incompetence of the George W. Bush administration, but for understanding the general state of U.S. foreign policy and the problem of its future conduct. If American foreign policy is now "in crisis," as the title of one of the books reviewed here asserts, is the task of the new administration to restore it to some former sensible balance, or to rethink it altogether? Any answer to this depends on whether one thinks the Bush-Cheney years represented a rupture with the past or was, in some sense, an expression - albeit an extreme one - of already existent tendencies.

Three of the books listed here by American authors are deeply, even personally, concerned with this question; they can be regarded as samples of the rather fraught debate over foreign policy occurring within the U.S. establishment. The fourth book, by British academic Simon Bromley, is an outsider's more scholarly, balanced and broad-ranging assessment of the role of American power since World War II and its possible role into the future. Curiously, despite the many differences of view and starting-point among the several authors represented, all come to remarkably similar conclusions about what part the United States should continue to play in the world, namely that of central buttress of a more or less benign liberal capitalist world order. Whether it is any longer equipped to play such a leadership role, however, has been called into question, not just by the Bush-Cheney experience, but by the likely effects of the ongoing economic crisis on America's preponderant power.

The fact of preponderant power, particularly military power, has of course been fundamental to the issue of American leadership, but just as important is the ambivalence with which that power has traditionally been regarded both within the 
United States and abroad. For Americans, the possession of great power has been a source of both exhilarating pride and deep misgiving, at once a great opportunity and a great threat. No nation ever took more to heart the maxim (derived historically from eighteenth century English dissenters and Whigs) that power inevitably corrupts, leading inexorably to tyranny. The temptation to abuse power threatens republican institutions and freedoms and, by extension, America's exemplary world mission, a fear that gives rise to the oft-observed, enduring tension between idealism and realism in U.S. foreign policy, as well as to that between "isolation" and engagement. The corrupting effects of power can be avoided, it has been assumed, only if power is used, not for self-aggrandisement and conquest, but for purely virtuous ends. A surprising number of American leaders (besides Woodrow Wilson, whose legacy is the centre of controversy in one of these books) have thus made the extraordinary claim that American foreign policy must be distinguished from that of other nations by its "selflessness." They have generally felt obliged to show how particular exercises of power abroad serve to support rather than undermine the universal cause of law and freedom, thus keeping alive the image of America as the "exceptional" nation.

Foreigners, as often as not, have treated such idealistic American pronouncements as hypocritical or self-deluding rationalisations for essentially selfish conduct. European commentary and analysis has frequently been severely critical of U.S. policy, whether on the basis of aristocratic or Marxist values, while antiAmericanism at the popular level is a recurrent phenomenon everywhere. Yet foreign attitudes toward the United States are often distinctly ambivalent, as resentment contends with the undeniable attractive power of America and its professed ideals. Such mixed attitudes are a distant echo of the hope and loathing with which Europeans first greeted the American experiment in free government over 200 years ago, and reflect the success of popular American culture since then in nurturing the universal "Idea of America" and transmitting it to the wider world. Of course, many other nations have cast themselves as exceptional, but none has succeeded like the United States in persuading so much of the rest of humankind to perceive them in the same mythological terms. No nation has ever been so concerned to be loved by others, nor so thought it deserved to be. To a surprising extent, others have wanted to love America if only its behaviour would let them. Thus while foreigners often bitterly criticise America, measuring it by its own high standards, they nevertheless continue to look and hope for its wise and effective leadership.

This has been both a boon and burden for American policy makers who have, on the one hand, been able to count on a rather generous fund of good will from other nations but, on the other, had to bear an unusual weight of world expectation as they try to defend their country's interests. The world will not let America be ordinary. It will always judge the faults of American leaders more harshly than those of nations whose history and ideology have never, in any case, promised better. But it will also judge them more harshly than those of other liberal democratic nations because America from the start made the role of liberal democratic exemplar part of its very identity.

\section{American values and the spread of democracy}

The depth of penetration of the national mythology in domestic culture means, too, that doubtful American actions abroad are liable to blow back at home, creating angst 
about the sullying of American purity and innocence and the fate of the exemplary mission. ${ }^{1}$ This is well demonstrated in the book by Anne-Marie Slaughter, whose title says it all: The Idea That is America: Keeping Faith with Our Values in a Dangerous World. This is less an academic book than a passionate sermon, fuelled by pain and disappointment at the apparent betrayal by government since $9 / 11$ of the essential American values that Slaughter proclaims and treats in successive chapters - liberty, democracy, equality, justice, tolerance, humility and faith.

The single biggest reason for international loss of faith in American leadership, says Slaughter, "is a pervasive global perception of American hypocrisy, that we say one thing and do another and that we make our own rules while accusing other nations of being rule-breakers" (177). Keeping faith with American values means avoiding such hypocrisy, but it also means "seeking and securing a world of ordered liberty" (36-7). Herein lies the rub. How is America to employ its power to both serve its own interests and fulfil its libertarian mission while avoiding the trap of tyranny or empire? Slaughter's answer is to integrate that power into an international system of "order and right" just as America did after World War II, abiding by the rules of the system, working through its multilateral institutions and organisations and treating fellow nations, not as vassals, but as partners in system maintenance.

The problem is that not all nations subscribe to a vision of "ordered liberty" that Americans have modelled on their own domestic constitutional arrangements. If the United States is often forced to act expediently and form ties, sometimes very close ones, with unsavoury and autocratic regimes, how is it nevertheless to keep faith with its values and encourage diffusion of these throughout the world? Slaughter's response is to offer a recipe (I am extrapolating here from the entire work) that combines prudence, honesty and humility. Prudence demands that sometimes unsavoury regimes be supported for some larger good, as for example the Egyptian has been for the sake of its continuing peace with Israel, which is in the interests of both the United States and the region. Though such compromises may be uncomfortable, honesty demands that administrations be frank with the American people about their necessity, particularly with the "impatient patriots" among them (72). Pretending that things are other than they are is to risk being branded as hypocritical. Yet honesty also implies a duty to express frankly to undemocratic partners American dissatisfaction with their political systems, for such partners have equal interests in sustaining ties with America even when criticism displeases them. Slaughter suggests the possibility of "graduated tiers of engagement, so that our criticism points more constructively at what governments can do if they desire closer ties" (73).

But, when all is said and done, Americans must simply recognise their own limits. It is here that humility comes into play (a virtue stressed, incidentally, by George W. Bush at the start of his presidency). America needs, says Slaughter, a global good neighbour policy reminiscent of Franklin Roosevelt's Latin American policy of 1936, but this means "having the humility to accept that America does not have all the answers to national and international problems, that global leadership is earned rather than assumed, and that collective problems require genuinely collective

\footnotetext{
${ }^{1}$ Inis L. Claude in 'The Common Defense and Great Power Responsibilities,' Political Science Quarterly 101 (5) (1986), 719-732 at 731, correctly observed that Americans "undoubtedly place a high value on having - not merely on being thought to have - clean hands and a pure heart; the discomfort of a guilty conscience, or even of nagging uncertainty about one's virtue, is not an easy thing to bear." The unwillingness of the U.S. to participate in global politics before the twentieth century, he wrote, is due in part to "the dread of dirty hands."
} 
solutions" (189-90). Humility also demands that, in talks with autocratic governments, Americans actually listen, even if they rightly reject much of what they hear. But what really will Americans usefully learn in such humble listening? Here we encounter the apparent impossibility of abandoning attempts to spread American values, assumed of course to be "universal." Slaughter says that in listening "we may also hear and understand things that will help us help or push these countries to build the underpinnings of true liberal democracy" (73). To put the matter bluntly but not unfairly, the goal remains and apparently must remain regime change. This must be so as long as it is impossible for a liberal democratic regime to accept as truly legitimate any non-liberal democratic regime. If the latter must be expediently accepted as members of a liberal international order dominated by the United States, it is purely on sufferance and with a constant long-term view to their fundamental reform.

Some poignancy is added to Slaughter's heartfelt manifesto by the fact, not actually mentioned in the book, that she was initially a liberal supporter of Bush's invasion of Iraq. In her contribution to the second volume reviewed here, The Crisis of American Foreign Policy: Wilsonianism in the Twenty-first Century, Slaughter indicates that this support was not primarily for the sake of spreading democracy. Given her line of argumentation, however, there is good reason to believe that it was the underlying motivation. The overt reason was to ensure the elimination of Saddam Hussein's weapons of mass destruction (WMDs), which was also, she argues, the Bush administration's main reason (the implantation of democracy, she says, being a merely a post hoc rationalisation when WMDs failed of discovery). She nevertheless points to the enabling role in her own case of a principle of which she is a firm supporter, namely that of a "responsibility to protect." This principle, initiated by Kofi Annan after the atrocities in Rwanda, Bosnia and Kosovo and developed by an International Commission on Intervention and State Sovereignty, re-characterised sovereignty in terms of both internal and external duties: internally, a state had a responsibility to respect the dignity and rights of its citizens; externally, it had a responsibility to respect the sovereignty of other states. The latter responsibility did not preclude an international humanitarian intervention in a state that failed drastically to meet its former responsibility. Though this principle of responsibility was not used (and, Slaughter argues, could not reasonably have been used) to justify the invasion of 2003, it nevertheless motivated her and others to view Saddam Hussein "through the lens of his horrific human rights violations, a view that in turn may have led us to be more willing to believe that he had nuclear or biological weapons without carefully scrutinising the available evidence. We were wrong" (109).

Having thus admitted some culpability, Slaughter swiftly shifts blame onto the U.S. and British governments who, she says, should have used multilateral processes more effectively to convince citizens that evidence of an imminent threat from Saddam justified the use of force against him or, failing Security Council authorisation, relented on their determination to invade. Far from condemning the invasion, however, this rather confused reasoning concludes by presenting a positive case for forceful intervention for purposes other than strict self-defence, namely to fulfil the responsibility to protect. Although Slaughter has argued that this principle is neither liberal nor conservative, but a "humanitarian" one based on a commitment to human rights that nearly every country has signed up to, she nevertheless notes that the concept "does indeed have classical liberal roots, in the sense that it supports individual citizens against the state" (101). And, in the final analysis, the duty to protect and the spreading of democracy turn out to be very closely allied in 
Slaughter's account. "The twenty-first century," she says, "like the twentieth century, must be made safe for democracy. ... For an American president in the first decade of the twenty-first century, [this] means a collective commitment to create the economic and social conditions in which liberal democracy can flourish, including, in extreme circumstances, enforcement of a government's responsibility to protect its own citizens" (109).

The point of Slaughter's essay in this book is to defend, with the help of fellow liberal internationalist Thomas Knock, "Wilsonianism" as an essential part of U.S. foreign policy. What may appear in The Crisis of American Foreign Policy to be a rather academic historical debate about President Wilson, his policies, motivations and influence is thus really a normative debate about the past and future of U.S. foreign policy.

\section{Wilsonianism in American foreign policy}

Defending Wilsonianism means, for liberal internationalists, defining it in a way that denies the label to the policies of Bush and Cheney and the neoconservatives who supported them. The so-called Bush Doctrine (particularly that of "preventative war") must be seen to be an aberration and not a continuation of liberal foreign policy traditions. Knock and Slaughter base their case on the fact that multilateralism, which is anathema to Bush-Cheney conservatives, was an essential element of the Wilsonian tradition. Their trenchant opponent in this volume, Tony Smith, argues to the contrary that there are four essential strands to Wilsonianism - the others being to spread liberal democratic government, to open international markets, and to exercise American leadership. Because multilateralism is the only one of the four that the Bush doctrine did not encompass, and because Smith claims that the spread of democracy was all along a central part of the doctrine and not a convenient add-on, the Iraq war can be fairly declared a genuinely Wilsonian enterprise.

Thus while Knock and Slaughter see the Bush-Cheney episode as marking a discontinuity in U.S. foreign policy, Smith sees essential continuity. Admittedly, the Bush Doctrine's insistence on perpetual American military supremacy was not a liberal invention (though Smith says that neoliberals and neoconservatives have now converged on this), but the intellectual roots of the doctrine's "pillar of purpose" - an insistence on the expansion of free market democracies - can be found, according to Smith, among liberals aligned to the Democratic Party (who he rather misleadingly terms "neoliberals;" 56-7). As a consequence, the disastrous course of the Iraq war has put Wilsonianism - and, by implication, the future of the entire liberal internationalist project - into crisis. John Ikenberry, another prominent liberal internationalist, appears to accept this contention in a measured but ultimately noncommittal introduction to the book. In an era of American unipolarity, he says, American power, rather than being a guarantor of multilateralism, might make collective decision-making more problematic. Unipolarity also raises the distressing problem "of how liberal internationalism can safeguard against abuses that turn enlightened intervention [of the kind that Slaughter defends] into imperialism" (23).

Slaughter thinks the best safeguard lies in a principle of only ever using force as a last resort and then only after wide consultation and agreement in multilateral forums, however messy and difficult the process. Beyond that, she absolutely accepts Smith's contention that the keystone of Wilsonianism is democratic government, but rejects the idea of "spreading democracy," which smacks of imperial imposition. She 
argues instead for "supporting liberal democratic parties and institutions in countries determining their own political future" (97). Slaughter rejects Smith's contention that liberal internationalists are now committed, like neoconservatives, to U.S. military primacy and says that they prefer instead to maintain a balance of power in favour of liberal democracies worldwide (91). In a footnote she claims this is a very important distinction, and points to the final report of the Princeton Project written by herself and Ikenberry which recommends that "The United States should work to sustain the military predominance of liberal democracies" (134). Critics like Smith might respond, however, that the de facto predominance of the U.S. even among democratic nations makes this is a distinction without a difference. Smith clearly thinks that the preponderance of American military power and the consequent temptation to deploy it unilaterally, as in Iraq, makes any element of Wilsonianism in U.S. foreign policy very dangerous - though he suspects that its deep resonance with American values and interests will cause it to endure in some modified form even if it would be better if it did not (57).

And in fact significant elements in American society seem determined that this will indeed be a prominent feature of the foreign policy of Barack Obama, whose administration has reacted to the democratic rhetoric of the Bush years by deemphasising the missionary imperative (despite the fact that some members of it have vigorously defended it in the past). ${ }^{2}$ In March 2009, a group of more than 120 American scholars, experts and thinktank representatives ranging from liberal Democrats to neoconservatives released an open letter to the president requesting that he focus his Middle East policy on reforms in the region toward more democracy and better protection of human rights. The letter argued that refraining from mentioning human rights and democracy - or playing down expectations for them, as Secretary of State Hillary Clinton did on her trip to China - was unacceptable for U.S. goals around the globe. Indeed, Clinton in her press conferences repeatedly stressed that the "three pillars" of American foreign policy would be defence, diplomacy and development, significantly leaving out the fourth " $D$ " - democracy promotion. The open letter sought to reinstate this fourth D. Its plea, it said, was not for a continuation of Bush foreign policy, whose inflated rhetoric was combined with highly equivocal action, but for a genuine fulfilment of the aims that Bush and Condoleezza Rice merely enunciated. The strategy recommended seemed identical to that advocated by Slaughter, which was to avoid a heavy imperial hand but to "encourage political reform not through wars, threats, or imposition, but through peaceful policies that reward governments that take active and measurable steps towards genuine democratic reforms." 3

One of the signatories of this letter was Larry Diamond, another archWilsonian who supported the Iraq adventure and even served as advisor to the Iraq Provisional Authority. In an interview, Diamond asserted that the strength of the open

\footnotetext{
${ }^{2}$ Michael McFaul, for example, who is special assistant to the president for National Security Affairs, wrote an article in 2002 in which he argued that, "The ultimate purpose of American power is the creation of an international community of democratic states that encompasses every region of the planet." McFaul, 'The liberty doctrine: Reclaiming the Purpose of American Power,' Policy Review (April 2002), 3-23. Samantha Power, a staunch advocate of armed intervention into humanitarian crisis situations, has also been appointed to multilateral affairs on the National Security Council. Her awardwinning books is A Problem from Hell: America and the Age of Genocide, New York, Basic Books, 2002.

${ }^{2}$ Ali Gharib, 'U.S.: Islamist Governments Not the Enemy, Say Mideast Experts,' Inter Press Service News Agency, March 13, 2009 (http://www.ipsnews.net/news.asp?idnews=46069; accessed 13 March, 2009).
} 
letter was that it was a bipartisan effort that cut across ideological lines. No doubt Tony Smith would take this as confirmation of the Wilsonian convergence of liberals and neoconservatives, proving that the Bush Doctrine, for all the cackhandedness and obstinacy with which it was implemented, was no simple aberration but rather an extreme manifestation of something deeply ingrained in U.S. foreign policy.

\section{The "return of history"}

Further support for the convergence thesis might be found in Robert Kagan's The Return of History and the End of Dreams. The controversial author of this short book rejects the label 'neoconservative' but is certainly no liberal. He has long advocated a muscular, typically neocon foreign policy founded on, and justified by, America's unique combination of power and righteousness. Kagan worked in the State Department during the Reagan administration, co-founded (with William Kristol) the Project for the New American Century in 1997, pushed the Clinton administration to adopt a policy of regime change in Iraq, and was one of the most prominent defenders of Bush's invasion of that country in 2003. He has therefore been held co-responsible for what many regarded as a disastrous shift in American foreign policy prompted by arrogance and ignorance.

The long and difficult trajectory of the Iraq war and the failure of its stated justifications (Saddam's non-existent WMDs) caused many neocons to reassess their previous positions. Perhaps the most telling recantation was that of Francis Fukuyama, whose book America at the Crossroads: Democracy, Power, and the Neoconservative Legacy, singled out Kagan in particular as a champion of the idea of benevolent American hegemony. Fukuyama argued that the neocons, having misattributed the fall of the Soviet Union to a virile show of American strength, wrongly assumed that the virtuous progress of history toward democracy could be accelerated by aggressive American agency. The misadventures of Iraq, he wrote, gave the lie to this, and future administrations would have to persuade the world, first, that America was good and, second, that it could be wise in its application of power, emphasising military power less and 'soft power' more, a strategy he described as "realistic Wilsonianism."

The very title of Kagan's book suggests a riposte to Fukuyama, whose most famous work was The End of History. ${ }^{5}$ Kagan rejects pusillanimous revisionism and adopts a policy of attack as the best defence (an extract from this book in the New Republic caused a furore accompanied by accusations that he was merely repackaging old positions). He argues that "the great fallacy of our era" (102) - an old Enlightenment one revitalised by the collapse of communism - is a deterministic belief in the progress of liberal ideas and institutions, an unwarranted confidence in humanity's inevitable forward march toward peaceful and prosperous coexistence. Recent developments - in particular the rise of China and the turning away of Putin's Russia from Western-style democracy - have revealed this pleasant vision to be a mirage. History has returned with a vengeance, propelled by the ambition, pride and fear of competitive, mutually suspicious and potentially hostile nation states. In an anarchic world, such states are not reliably restrained by international laws and institutions, or even by growing economic interdependence, and naturally seek

\footnotetext{
${ }^{4}$ Francis Fukuyama, America at the Crossroads: Democracy, Power, and the Neoconservative Legacy, New Haven, Yale University Press, 2007.

${ }^{5}$ Francis Fukuyama, The End of History and the Last Man, London, Hamish Hamilton, 1992.
} 
enhanced security in military preparedness. Moreover, an access of power inevitably breeds discontent with the status quo and a desire for greater influence in the world, as well as for the respect and honour that great power always commands. Witness Iran with its nuclear ambitions, or even democratic India whose economic transformation has caused "the power of argument" to be displaced by "the argument of power" (42).

This sounds perfectly realist, yet Kagan argues that it is not just differentials of power that matter - values do too. Ideological competition may be a thing of the past, but the world continues to resist convergence in value terms because some of the major players are autocracies. The leaders of China and Russia and nations that take heart from their example are not merely cynical autocrats; they believe in autocracy. Democratic factionalism, they claim, is dangerous to stability, and so-called universal liberal values are merely the impositions of Western power. The international liberal order does not imply progress for them but oppression, for it questions "the fundamental legitimacy of governments, which for autocracies can be a matter of life and death" (67). Their foreign policy must therefore include the defence of autocracy itself, and this presents a much more significant challenge to the West than Islamism's ultimately futile resistance to modernity. The world of competitive nation states is thus patterned by a larger competition between democracies and autocracies, and since democracy will not come about automatically, one must choose which side to support.

If there are few explicit retractions in this analysis, there is certainly a shift of emphasis from Kagan's best known previous work, Of Paradise and Power. There he contrasted an effeminised Europe indulging a fairy-tale world of international law, multilateral cooperation and perpetual peace with a United States that remained "mired in history," wielding power (unilaterally if necessary) in a Hobbesian world where security relied ultimately on military might (which, by the way, provided the essential shield under which a weak Europe could indulge its utopian fantasy). ${ }^{6}$ This contrast remains but is softened in the interests of advocating a united democratic front against the challenge of autocratic power. Kagan floats the idea of a "concert of democracies" that would "complement" the United Nations - whose Security Council is largely nullified by the split between democracies and autocracies - and other global organisations (97). In keeping with his newly multilateralised approach, Kagan asserts the importance of American power but in somewhat chastened form, a reflection of the erosion of legitimacy suffered through recent unilateralist actions. American power may not be always wisely used, says Kagan, but would anyone else do better? And at any rate this power remains vital for balancing and moderating regional powers who distrust and despise one another much more than they hate America. The safest bet thus remains an international system based on "one superpower and several great powers" (92), in other words on the continuance of benign American hegemony with the crucial support of democratic allies.

Kagan's ultimate position is not far from that of Slaughter or Ikenberry, the latter of whom has argued over two decades that the liberal international system constructed during the Cold War depended on America acting as a "restrained hegemonic power." Other Western countries acquiesced willingly in this non-zero sum system because they shared America's democratic and capitalist-development values and benefitted from the order created. Ikenberry presumes, in other words, that

\footnotetext{
${ }^{6}$ Robert Kagan, Of Paradise and Power: America and Europe in the New World Order, New York, Alfred A. Knopf, 2003.

${ }^{7}$ For a reprinted collection of essays, see G. John Ikenberry, Liberal Order and Imperial Ambition, Polity Press, Cambridge, 2006.
} 
power may support international community rather than destroy it. It is not clear that Kagan can logically assume the same, though his prescriptions seem to require it. Kagan insists that we cannot speak of an "international community" where there is no agreement on international norms, morality or conscience (76), but the corollary of this is that we can speak of such a community when common norms exist. This seems confirmed by his hope for a concert of democracies and his comment that "a democratic Russia and China would be better international partners" (99).

The problem is that such moderate views sit oddly with Kagan's initial, ultrarealist analysis of the apparently invariable behaviour of all nations which, never satisfied with a little power, must seek to expand it, thus perpetuating the endless competition of power politics that marks the "return of history." Kagan's real lesson is that the international triumph of liberal democratic values, implicitly leading to a less dangerous world, is not preordained but must be politically won, material and military power being not irrelevant in the contest. But to presume, as Kagan seems to, that such a triumph is even a possibility is already to transcend the narrow power realism with which he begins. Indeed, it is difficult in the end to see what, apart from some residual contempt for existing multilateral organisations, separates him from the liberal internationalists whose "soft" approach is supposed to contrast with his own tough-mindedness.

This, of course, may be as disturbing for the liberals as for Kagan. They might argue that he, with his grand conflict between liberal democracies and autocracies, is misguidedly attempting to restore the Manichean order of the Cold War that was the essential binding element of the modern American conservative movement. Yet the basic tenets of liberal internationalists, as we have seen, implicitly divide the world in exactly the same way by assuming the fundamental illegitimacy of non-liberal democratic regimes and the need to "help or push" them toward reform for the sake of a more just and peaceful world. Kagan's proposed concert of democracies, moreover, unavoidably echoes the Community of Democracies organised by Madeleine Albright's State Department in 2000 as well as similar ideas supported by Slaughter and Ikenberry in the Princeton Project.

Superficially attractive as such a community might seem, as a serious international forum it seems like a non-starter or simply a bad idea. If its point were merely to discuss and negotiate differences that exist between democracies, which are many, it may be perfectly acceptable, but if it were to seem like a ganging-up on the non-democratic world it may simply provoke negative reactions that would make solution to many pressing international problems - Islamist terrorism, climate change, mass migration, proliferating WMDs, pandemics and so on - more difficult. The global economic crisis that began in mid-2008 demonstrated beyond all doubt how closely and inseparably interlinked are the fortunes of all nations, democratic and non-democratic, and how essential (and difficult) it is to achieve the genuinely coordinated action that needs to be taken (and here, notably, the most acute differences were not between democracies and autocracies but between Europe and the rest of the world). It is not obvious that emphasising and thus possibly exacerbating the differences between democracies and autocracies is of much use to the practical diplomacy required to manage this and many other issues.

This, however, leaves the issue of U.S. foreign policy in uncertain terrain. If democracy promotion cannot be central to the agenda, can it really be taken off altogether? The question remains as to precisely how American power should be configured in the future and what overarching policy it should be called upon to support. 


\section{American power and the maintenance of international order}

Any useful approach to this question requires thinking broadly about what we might call America's "natural" role in building and maintaining an international order made up of juridically sovereign but economically deeply interconnected nations.

Bromley's book, American Power and the Prospects for International Order, provides a thoughtful and helpful analysis in this regard. Methodologically, the book focuses on the developing logic of an international capitalist system in which America, and the ideology of "Americanism," play central hegemonic roles. Given this critical-political-economy (rather Gramscian) style of analysis, one might expect that American power would be subject to the usual radical arraignment for its imperialistic tendencies, but Bromley avoids, and indeed refutes, simplistic radical readings.

His analysis, interestingly, affirms that the neoconservative intervention was not a major aberration but rather a "return to normalcy" in U.S. foreign policy. The central argument is that that policy since World War II, whatever realist calculations of power and balancing it involved, was always "guided by a dynamic and broadly liberal vision of the fundamental transformation of international order set in train by the advent of modernity, understood more or less in the terms set by modernization theory" (38). (One of the early strengths of this book is a reprise of the work of Walt Rostow, the prophet of modernisation theory, revealing the breadth, prescience and, one must add, calculated ruthlessness of his vision of modern development.) Because the belief that America had both the means and right to reshape the world order was practically "a defining element of the American ideology" and very widely accepted, it follows that the neoconservative movement was very largely in tune with dominant post-war paradigms of American geopolitical thinking (39).

Of course, neoconservatives could hardly be as optimistic as early modernisation theorists about the progress of liberal third world development, particularly in geostrategically important regions like the Middle East. On the other hand, they were much more optimistic in their estimation of the role of military power in fostering liberal transformation in such regions for the sake of achieving a benign American world order. Such transformation was expected to reorient the balance in world affairs in favour of the American project, threatened as it seemed not just by Islamist revolt but more seriously by illiberal countries like China and Russia that had become economically more integrated in the world system, by 'rogue' states like Iraq, Iran, Serbia and North Korea, and even by a Europe that had become internally indulgent and externally neglectful.

Bromley notes, with regard to the notorious 1992 Defense Planning Guidance penned by neoconservatives during the elder Bush's presidency, that advocacy of maintaining American military unchallengability in perpetuity did not assume total dependency on (realist) geopolitics of power balancing. It included a (liberal internationalist) recognition "that strategic restraint and an inclusive and long-term definition of US interests, making space for the interests of others, were important if military primacy was not to promote potentially adverse competition and perhaps direct challenges in the future to institutionalization of US leadership" (44). But in the neoconservative alliance of convenience with the "nationalist conservatives" of the Bush administration, formed on the basis of shared concerns over Iraq and galvanised and empowered by $9 / 11$, such subtleties were overridden by the latter's "visceral 
antipathy to international entanglements" (45). What was genuinely distinctive in the Bush doctrine was the belief that the costs of cooperation with others were greater than the benefits and that, American power being what it was, others must inevitably follow where the U.S. led. The administration's gravest error (one too often made also by radical critics) was to assume that military power is easily fungible into political influence. Bromley's general argument is that "military pre-eminence can only be effectively parlayed into a stable and durable political leadership when it advances the coordinated interests of an expanding, yet still imperial, liberal capitalist order" (51).

The problem and challenge for the United States is that, in fostering the development of a post-colonial liberal world order - characterised not by oldfashioned direct control and exploitation but by permeable borders, free flows of trade and capital, mutual recognition of rights of contract and property, coordinated alignments of different jurisdictions, and so on - America, despite its military predominance, inevitably ceases to be the centre, or only centre, of capital accumulation and technological innovation. The logic of economic dispersal is that "each state - including increasingly even the United States - is compelled to take responsibility for managing its domestic order and external policies in ways that sustain the international conditions of capitalist development" (69). This makes coercion of very limited utility since it tends to work against the now common interest in mutual adjustment and coordination. An interdependent system does not exclude domination and certainly does not mean equality, but at its centre is a system of rules which, to produce positive-sum gains, all participants must have an interest in observing. Although the United States alone has the capacity to violate the rules with impunity, "it is hard to see how America's long-term interests can be advanced in this manner" (97). Bromley explores at some length how the logic of this system works in relation to world oil (Chapter 3).

Bromley notes that, in the nuclear, post-colonial age, the utility of military dominance to compel adversaries is much diminished, raising the question of how military primacy is to be turned to economic and political advantage. He argues that "seeking military primacy over a range of powers - Western Europe, Russia, China, India, etc. - when the strategic alignments among them are varied and changeable, and when all subsist in a world market that can only be governed by a significant degree of common endeavour, does not translate into political leadership" (200). The United States can usefully employ its might to act as a power balancer among regional rivals, but its capacity to determine the shape of economic coordination will inevitably diminish over time as other capitalist centres develop and the U.S. is forced to coordinate with them. Indeed, unlike all previous imperial projects, America's modernising post-war international order included, as a logical component, the longterm relative economic decline of the chief hegemon. America's potential leadership role thus remains real but must be understood for what it has always been and for how it must alter over time. Bromley's conclusions are therefore (as he admits) very much aligned with those of Ikenberry, who has argued that the "global empire," if it can be called such, is not essentially an American empire but an empire of capitalist democracy to which even America must accommodate itself. ${ }^{8}$ The United States must understand, Bromley concludes, that it "has been the principal architect and beneficiary of the post-war capitalist international economic order, and that if it now attempts to use the uni-polar moment to abandon strategic restraint and pursue its

\footnotetext{
${ }^{8}$ Ikenberry, Liberal Order and Imperial Ambition, 2006, 8, 3.
} 
interests at the expense of other major centres of economic power, it will squander its remaining international leadership" (205).

\section{The future of U.S. foreign policy}

The consensus underlying all the books reviewed here, despite their varied origins and intentions, is that the United States is deeply, even necessarily committed to an international capitalist order founded on interdependent liberal democratic states whose number, if the system is to be complete and stable, should be steadily augmented over time. This seems undeniable. The United States was a trading nation at and even before its birth, and its ideological devotion to Lockean natural rights committed it to a liberal theory, not just of private property, but of a developing commercial civilisation. As we have noted, America conceived of its own experiment in free government and economic development as more than a selfish national project, in fact as a universal example that all the world would or should someday imitate. It had a mission that must be safeguarded by avoiding political entanglements with wily and war-ridden Old Europe from whence its own civilisation had sprung. Yet once the United States had become the richest and most powerful industrial capitalist country on earth, deeply and increasingly bound up in trade, investment and rivalry with other industrial nations or empires, the question for its leading statesmen inevitably became (notwithstanding the nostalgic longings of isolationists) not whether it should politically engage with the wider world, but on what terms. All the arguments between imperialists and anti-imperialists, unilateralists and multilateralists, nationalists and internationalists, realists and idealists over the years have been centrally concerned with this issue. The moral dimension, as Anne-Marie Slaughter rightly indicates, was how to engage without compromising or destroying the values the nation stood for and which allegedly constituted the "last best hope of mankind."

Woodrow Wilson's answer, under pressure of European war, was to engage the world by helping transform it for its own good - that is, for the sake of peace, prosperity and democratic self-rule. His failure seemed to confirm the futility and danger of deploying American military power even in a good cause. Disillusionment led to a period of withdrawal that was deepened by the onset of the Great Depression and a defensive economic response that further disrupted world trade. As dangerous fascist regimes arose in Europe and Japan, therefore, the United States did nothing until the Japanese attack on Pearl Harbour shocked it from its torpor.

The lesson of these interwar years was not lost on the American leaders who would construct the foundations of the liberal world order after the horrors of World War II - Cordell Hull, Hans Morgenthau, Franklin Roosevelt, Harry Truman, George Marshall and others. The power of evil could only be opposed and defeated by the power of good people, which must henceforth be permanently engaged. Americans identified two main factors that had led to catastrophe: the refusal of America to commit its power to support the League of Nations and thus preserve peace, and the destructive effects of economic nationalism and discriminatory trade. These would be addressed in the post-war period by deploying U.S. military might on a global scale, by committing America to the new United Nations Organisation, and by establishing the Bretton Woods system of liberal international regulation that would manage trade

\footnotetext{
${ }^{9}$ For my elaboration of the argument adumbrated in this section see John Kane, Between Virtue and Power: The Persistent Moral Dilemma of U.S. Foreign Policy, New Haven, Yale University Press, 2008.
} 
and exchange difficulties and prevent nations resorting to devaluation, protectionism, or domestic austerity measures that caused unemployment. At the same time, the World Bank would invest the funds of richer countries in developing economies thus furthering the liberal internationalist project.

This was conceived as a truly global cooperative enterprise that would include even America's wartime ally of convenience, the Soviet Union (always an improbable hope given the liberal capitalist framework). With the onset of the Cold War, however, American power, instead of underwriting a universal order, became dedicated to the defence of the Free World against "expansive communism." This led eventually to the militarization of American society on a scale hitherto unimaginable and embroiled the United States in the kind of unsavoury balance of power politics American diplomacy had always excoriated and that its critics, including its domestic critics, condemned. ${ }^{10}$ Moreover, virulent anti-communism played destructively in domestic politics and encouraged American leaders, from fear of being labelled "soft on communism," to undertake military commitments in small peripheral countries of otherwise little interest to Americans. The liberal consensus that had sustained American leadership of the West unravelled in Vietnam, and what began as a noble effort to found the peace and stability of the entire world ended by producing internal dissension and furious turmoil at home.

Larry Diamond, in the interview noted above, argued that the Obama administration had no foreign policy at all, since simply rejecting Bush did not amount to a policy. Yet it could be argued that the "crisis" brought on by the BushCheney years was only a consequence of the fact that the United States had not had a clearly-defined foreign policy since the cracking of the post-war consensus. This at least is what that famous "realist," Henry Kissinger, has long been saying and lamenting. Kissinger claimed that the fault lay precisely with the regrettable but persistent strain of Wilsonian moralism in U.S. foreign policy that was founded in exceptionalist confidence in the unrivalled virtue and unrivalled power of the United States. The "tragedy" of Vietnam, he wrote, divided American society and destroyed faith in the uniqueness and universal relevance of American values, disabling all later attempts to develop a new, rational foreign policy consensus. Americans after Vietnam could no longer confidently assert their own values or feel comfortable about imposing them on others, and were consequently at a loss as to what to do with their own predominant power. ${ }^{11}$

Kissinger was surely correct about this. The problem with American military power after Vietnam was not that it had been significantly diminished - it had not but that it had been somehow emasculated, creating an enduring dissensus between Rightist "hawks" and Leftist "doves." The former, arguing that the full extent of America's military might had not even been deployed in Vietnam, were deeply resentful of what they regarded as the domestic betrayal that had produced an unnecessary defeat and wished to wipe out the humiliation of Vietnam through convincing and wholehearted assertions of American power. This required, too, the

\footnotetext{
${ }^{10}$ Noam Chomsky is, perhaps, the most prominent and persistent of these critics. See, for example, his (with Robert W. McChesney) Profit over People: Neoliberalism and Global Order, New York, Seven Stories Press, 1998; Hegemony or Survival: America's Quest for Global Dominance, $2^{\text {nd }}$ edn., Crows Nest NSW, Allen \& Unwin, 2004.

${ }^{11}$ Henry Kissinger, Diplomacy, New York, Simon \& Schuster, 1994; Does America Need a Foreign Policy? New York, Simon \& Schuster, 2001. See also Richard A. Melanson, American Foreign Policy since the Vietnam War: The Search for Consensus from Nixon to Clinton, Armonk, NY, M.E. Sharpe, 2000 .
} 
restoration of presidential authority sapped by popular and congressional distrust after Vietnam and Watergate. Such hawkish dreams were largely frustrated by the persistence among populace and politicians of the "Vietnam syndrome," but their influence would be increasingly felt as more radical kinds of conservative gained ascendancy over the liberal wing of the Republican Party following the fall of Nixon. ${ }^{12}$ Meanwhile the Democrats, after the candidacy of George McGovern in 1972, moved further Left to become the party of injured American innocence, as suspicious and fearful of military power as had been America's peace activists earlier in the twentieth century.

The result was not merely dissensus on foreign policy but an obsession with either the possibilities or dangers of military power that, in the long run, elevated the military dimension of international relations above the diplomatic. Discussions of foreign policy post-Vietnam tended to revolve endlessly around the question of when and how the use of military force could be justified. (It is sobering to think that the famous Weinberger-Powell Doctrine, with its insistence on strictly national interests, overwhelming force, a swift victory and a clean exit might have precluded American participation in World War II.) It was not surprising, then, that when an ultraconservative administration came to power in 2000, its foreign policy team should be made up of figures whose predilection was for military rather than diplomatic affairs. Most had spent their government careers either in the armed forces or as Defense bureaucrats striving to build America's military strength (in Donald Rumsfeld's case to reshape it for a new era). It was strange but telling that those with actual army or navy experience - the State Department's Powell and Richard Armitage, respectively, who had both served in Vietnam - were the cautious ones with respect to military force, while the men they contemptuously referred to as the "chicken hawks" Cheney and Rumsfeld, Paul Wolfowitz and his aide "Scooter" Libby, all at Defense were conservative ideologues ready and willing to wield it when the occasion arose, as it did after September 11, 2001. None had the background of a Dean Acheson or an Averill Harriman or the propensities of even a George Marshall who, though an indomitable old soldier, left his most considerable mark in the field of diplomacy. ${ }^{13}$

Meanwhile, the end of the Cold War and the greater prominence of other issues in world affairs had also caused a significant shift on the Left with respect to military power. With the nation apparently secure in itself, questions arose about when to intervene for humanitarian reasons in regional conflicts where raw American interests were not obviously at stake. Many liberals who had regarded American military power since Vietnam as dangerous and illegitimate became converted to the possibility, or even necessity, of its use for preventing genocidal crimes or supporting democratic governments abroad. Who else, after all, had the means? ${ }^{14}$ Thus 1994

\footnotetext{
${ }^{12}$ The unfortunate displacement of Burkean conservatism by reactionary conservatives (reactionary in that their aim was to restore the ancien pre-New Deal regime) obsessed with doctrinal purity and the prosecution of a civil war of their own devising is beautifully adumbrated by Sam Tanenhaus in "Conservatism is Dead: An intellectual autopsy of the movement," The New Republic, February 18, 2009, 12-17.

${ }^{13}$ James Mann, Rise of the Vulcans: The History of Bush's War Cabinet, New York, Viking, 2004, 273-4. Mann notes that whenever the conservatives felt offended by Powell and Armitage, they accused them of having been "captured" by the State Department's bureaucracy. For the influence of the military on foreign policy see Dana Priest, The Mission: Waging War and Keeping Peace with America's Military, New York, W. W. Norton, 2003.

${ }^{14}$ On this change of mind of human rights movement, see David Rieff, At the Point of a Gun: Democratic Dreams and Armed Intervention, New York, Simon \& Schuster, 2005. Cases like Bosnia
} 
witnessed the surprising sight of liberals who had opposed the first Gulf War pressuring Clinton to order an invasion of Haiti to replace the democratically elected leader Jean-Bertrand Aristide, overthrown in a military coup, while Senator Bob Dole, ex-President Bush, James Baker and Dick Cheney warned against it on the ground that no important American interest was at stake. It was by this route that liberal interventionists, of whom Slaughter might be taken as representative, should find themselves surprisingly aligned with a conservative administration that, after $9 / 11$, abandoned its formerly "hands-off" foreign policy to pursue military interventionism rationalised in part by democratic and human rights rhetoric. This convergence, uneasy as it was, did not remotely approach a deliberative consensus on American foreign policy. Yet, as the books reviewed above indicate, the sorrow and shame of the BushCheney years did at least revive the debate about the essential elements of a foreign policy that could conceivably command broad public assent.

What seems clear is that any supposed choice between realism and idealism is itself unrealistic. Certainly it is often assumed that, if Wilsonianism represents the "idealistic" strand of American policy, then repudiating it means falling back on straightforward "realism." It used to be said that Vietnam had forced Americans to make this choice, once and for all, with the Right holding out strongly for powerrealism and the Left for moral idealism, yet the matter was hardly so simple. For one thing, conservatives could no more escape the gravitational pull of the missionary mythology so deeply implanted in American consciousness than could liberals. Conservatives after World War II were drawn out of their traditional isolationism, not just by their realisation of the potentialities of American power, but by their own anticommunism commitments, so that their foreign policy was always tied to the concept of a crusade against evil, with Islamism easily substituting for communism after the end of the Cold War. Liberal doves, meanwhile, could not ignore the sheer, blatant fact of American power upon which other nations relied, nor avoid the question of how to use without abusing it. Despite their suspicions of military power, postVietnam liberals saw their task not as diminishing global involvement but as moralising and purifying it.

For another thing, the power-centred realism of international relations theory, whether classical or neo-, seems no more helpful for managing the complexities of modern global governance than does overtly crusading Wilsonianism. And if, as I believe, the common assumption of the books reviewed here is correct - that America is by its nature, history and power unalterably committed to supporting and expanding the liberal capitalist international order it has had such a large role in creating - then both its value and practical commitments are already irrevocably settled. Condoleezza Rice, in an address at Davos in January 2008, summed the case up succinctly with what she called her "American realism": "We do not accept a firm distinction between our national interests and our universal ideals, and we seek to marry our power and our principles together to achieve great and enduring progress."15 Of course things cannot always be so clear, and their will always exist the potential for tension between the parochial interests of the United States and its international

and Rwanda made Rieff himself an interventionist in the 1990s but he took a turn against "utopianism" after George W. Bush's invasion of Iraq in 2003.

${ }^{15}$ Condoleezza Rice, "Keynote Address at the Annual Meeting of the World Economic Forum," Davos, Switzerland, January 23, 2008 (http://www.state.gov/secretary/rm/2008/01/99624.htm accessed 14.2.08). 
responsibility, creating what Bruce Cronin has called the "paradox of hegemony.",16 Yet such tensions are inherent in any leadership position and must be managed occasion by occasion, as they largely were in the post-war period among Western powers. The real question is whether the United States now has the capacity and readiness for sustained leadership of that kind and, if it has, how that leadership should be prudently exercised.

The question of capacity must be raised, first, because of the shaking of international faith in American leadership caused by actions and attitudes of the BushCheney years. The surge of goodwill toward Obama after his election, and broad world approval of his early foreign policy moves - announcing the closure of Guantanamo, prohibiting torture, speaking to Iran and so on - showed that moral authority was not irrevocably lost, though the road back might still be long and bumpy. Second, and more serious, is the issue of the long-rolling economic crisis, addressing which has saddled the U.S. government with huge deficits into the foreseeable future and raised doubts about its ability adequately to finance on-going programs. The fact that this crisis had its origins in hugely imprudent home lending and lax financial sector practices in the United States also delivered a severe blow to American credibility internationally, seeming dramatically to signal the modern shifting of the global economic centre of balance. The once-powerful engine of the world economy, even as its own public infrastructure crumbled from neglect and lack of investment, turned itself from a producer to a consumer nation. Worse, consumption was paid for by debt founded on inflated house values fuelled ultimately by the lending of new producer nations, particularly China, to the U.S government. Although no nation could escape the economic fallout from the freezing of credit that followed the collapse of giant banking and insurance companies, it was hardly surprising that the reaction of some foreign countries - most notably Germany and Russia - toward the Unites States should be a mixture of blame and contempt. China, worried about the value of its huge dollar holdings tied up in U.S. government securities, began expressing a talk about a shift from the U.S. dollar as the unit of international currency. Even as Obama spoke of reasserting responsible American leadership, doubting heads of state around the world questioned whether America's leadership moment had finally passed. In the United States itself, Robert Pape argued that "If present trends continue, we will look back at the Bush administration years as the death knell of American hegemony."17

And yet a troubling question hovered about how a world of economically interlinked but politically disparate nations might fare without some relatively benign hegemon capable of bringing its considerable weight to bear to reduce friction at the many points it is liable to occur, thus keeping the system in some sort of order. The alternative to American leadership is in fact a leaderless world, for there is no other candidate for moderating hegemon, nor is there likely to be for a long while. Kagan is correct at least in saying that the distrust of many nations for one another far outweighs their distrust or resentment of America. Whatever the past sins of the United States, it still has a role to play if only it can restore its fortunes and repair an economy whose health is fundamental to its future influence.

Supposing this can be done in the coming years, and the capacity for leadership be restored, how may such leadership be optimally exercised? It is hard not

\footnotetext{
${ }^{16}$ Bruce Cronin, "The Paradox of Hegemony: America's Ambiguous Relationship with the United Nations," European Journal of International Relations 7 (1) (2001), 103-130.

${ }^{17}$ Robert A. Pape, "Empire Falls: First Draft of History," The National Interest, January/February, 2009, 21-34 at 21.
} 
to hope, in light of the recent past, for greater prudence in the hegemon with regard to its oversight of both economic and international affairs. With respect to the latter, it is worth contemplating what Robert Tucker and David Hendrickson regard as the "four pillars" of U.S. legitimacy in leading the Western alliance after the war. These were: general respect for international law, particularly as figured in the United Nations Charter (despite some clear transgressions); commitment to consensual modes of decision-making and compromise (it was notable that when the United States acted in defiance of international opinion over Vietnam its legitimacy reached its lowest point in post-war history); a reputation for moderation in policy (enhanced by genuine American reluctance to take up responsibilities as guardian of the peace and the worry of European leaders that the United States might once again be tempted to isolationism); and post-war success in preserving peace and prosperity within the community of advanced industrialised democracies (the fact that old-fashioned great power conflict can be considered now extremely unlikely seems, after the catastrophes of the first half of the twentieth century, like deliverance from unspeakable evil). ${ }^{18}$

These describe, in fact, the characteristics of the "restrained hegemon" that Ikenberry argues created the Western system, one which, however partial and flawed, deserved to be preserved and extended. Had this been merely an alliance welded together by fear of a larger menace, Soviet communism, it should have crumbled into anarchic competition as soon as that menace disappeared, but it did not. It was seriously threatened only when an administration came to office which, even if it understood its logic, never accepted the constraints the system placed on the free use of American power. What Ikenberry interpreted as the virtues of hegemonic selfrestraint, the Bush administration regarded as the sullying of American sovereignty, an attempt by hostile or malevolent Lilliputians to tie down the benevolent giant and prevent it from establishing its benign imperial reign. Present and future administrations must recover lost ground, and this will certainly require greater realism - not IR theory realism, but a more commonsense form that implies a soberly realistic assessment of, not just what should be done, but of what can and cannot be done - the sort of realism, in other words, repudiated by the Bush administration with its notorious contempt for the "reality-based community." If the Bush-Cheney period provided any certain lesson it was that American military power, however great, cannot simply create whatever reality its wielders desire, especially when desire is informed, as one commentator writes, by "fantasy, faith and willful indifference." 19

The foreign policy style of the elder Bush, a president as committed to American leadership as any other, was labelled "practical intelligence" by its practitioners and "patrician pragmatism" by scholars. ${ }^{20}$ It was a style appropriate to a world made suddenly more complex and uncertain by the disappearance of Eastern and Western blocs that had dominated hitherto. The world has become no less complicated or uncertain since then and, in addition, American prestige and capacity have suffered serious blows, diminishing options. Pragmatism, hopefully guided by

\footnotetext{
${ }^{18}$ Robert W. Tucker and David C. Hendrickson, "The Sources of American Legitimacy," Foreign Affairs, November/December 2004 (http:/www.foreignaffairs.org/20041101 faessay83603/robert-wtucker-david-c-hendrickson/the-sources-of-american-legitimacy.html - accessed 30/3/09).

${ }^{19}$ See Fred Kaplan, Daydream Believers: How a Few Grand Ideas Wrecked American Power, John Wiley \& Sons, 2008.

${ }^{20}$ George H.W. Bush and Brent Scowcroft, A World Transformed, New York, Knopf, 1998, 35; C.V. Crabb and K. Mulcahy, "The Elitist Presidency: George Bush and the Management of Operation Desert Storm," in R. E. Waterman, ed., The Presidency Reconsidered. Itasca, IL, D.E. Peacock, 1993, $275-330$ at 281 .
} 
wisdom, must remain the order of the day, and the Obama administration has seemed in its first year to show understanding of this. As far as the Wilsonian question goes, America is unlikely ever to relinquish its predilection for the spread of liberal democratic market economies, but the essence of great leadership has always been to accept and manage the world as it currently is while drawing some clear line that principle dictates must be defended firmly. And it must be remembered that the times will be as challenging for all other nations as for America. Almost all of them are committed, if to nothing else, at least to "development," and development on the liberal model to which America itself is indelibly committed. How far they will themselves be forced to adjust their polities to the cultural exigencies of that model, independent of American leadership or pressure, remains a moot but significant question. 